\title{
ANALYSIS OF EARTHQUAKE PREPAREDNESS MEASURES IN STUDENTS AT ELEMENTARY SCHOOL, DENPASAR, BALI
}

\author{
Yustina Ni Putu Yusniawati, Putu Inge Ruth Suantika
}

Institute of Technology and Health, Bali

\begin{abstract}
Background: In addition to unsuccessful policies to prepare communities for disaster reduction, the high risk of earthquakes and their harmful consequences indicate that more consideration should be given to social factors in this regard. All community shelters are vulnerable to disasters, especially children, so efforts are needed to determine disaster preparedness factors for elementary school students in Denpasar City. This study aimed to analyzed of earthquake preparedness measures in students at elementary school, Denpasar, Bali.

Subjects and Methods: This was a descriptive study conducted at an elementary school in Denpasar from January to September. A sample of 350 elementary school students in Denpasar whose schools have a disaster preparedness school (SSB) program selected by purposive sampling. The inclusion criteria were elementary school students grades 5 and 6 in Denpasar City, who can read fluently and are willing to be research respondents. The exclusion criteria were respondents who refused to be research subjects. The data were collected by 40 questions, where knowledge was 10 items, attitude was 10 items, facilities and infrastructure were 10 items, and IEC was 10 items. The data was analyzed by descriptively

Results: The preparedness factors of elementary school students in facing earthquake disasters were still low. There were five earthquake preparedness factors for elementary students in Denpasar, namely (1) experience, (2) knowledge, (3) attitude, (4) facilities and (5) infrastructure, and IEC. The dominant knowledge variable of elementary school students is less than $233(63.7 \%)$, the prevalent attitude variable is negative 244 (64\%), the prevalent facilities and infrastructure variable are less than 215 (61.4\%), and 300 (85.7\%) dominant information and education communication.

Conclusion: It is essential to be able to improve these preparedness factors with a variety of continuous education and training for elementary students, and health workers should work together with regional disaster management agency to establish disaster prepared schools in Denpasar City.
\end{abstract}

Keywords: preparedness factors, students, and earthquake

\section{Correspondence:}

Yustina Ni Putu Yusniawati. Institute of Technology and Health, Bali. Jl. Tukad Balian no. 180 Renon Denpasar-Bali. Email: yustinaindrayana@gmail.com. Mobile: 087860000191

The $7^{\text {th }}$ International Conference on Public Health

Solo, Indonesia, November 18-19, 2020 | 69

https://doi.org/10.26911/the7thicph.01.24 